\title{
ORGANIZATIONAL NEURO STUDIES AND ETHICAL CONSIDERATIONS
}

\author{
ÖRGÜTSEL DAVRANIŞ ALANINDA NÖRO ÇALIŞMALAR VE ETİK \\ HUSUSLAR
}

\section{Ayşe ESMERAY YOĞUN ${ }^{1}$}

\begin{abstract}
Cognitive neuroscience as a multidisciplinary field, seeks to understand human behavior at the intersection of social, cognitive, and neural spheres of science. Neuroscience can help organizations become more effective by support productivity and employee satisfaction. With this paper, it is aimed to contribute to literature with the potential promise of cognitive side of organizational behavior as synergic young field. The main aim of this paper is to discuss neuroscience techniques and ongoing studies with ethical perception that already existed in the organizational behavior field. This new field has emerged to investigate the cognitive neuroscience of organizational behavior and so, organizational scholars have begun to take note of the potential implications of neuroscience at workplace research, the popularity of new field is attested by recent conferences, special issues of journals. But the theoretical codes of this new science derive from an uneasy embracing of two different field of social behavior: sociobiology and evolutionary psychology on the one hand, and social psychology on the other.
\end{abstract}

Keywords: Neuroscience, Organizational Neuroscience Techniques, Social Cognitive Neuroscience, Organizational Behavior, Ethical Considerations.

\section{$\ddot{O} \mathbf{z}$}

Bilişsel sinirbilim, çok disiplinli bir alan olarak, insan davranışlarını sosyal, bilişsel ve sinirsel açıdan anlamaya çalışmaktadır. Sinirbilim alanında yapılan çalışmalar, işletmelere verimlilik ve çalışan tatminini arttırarak destek olabilir. Bu çalışma ile, sinerjik genç bir bilim dalı olarak, örgütsel davranışın bilişsel tarafının yaratacağı firsatlardan bahsedilerek literatüre katkıda bulunulması hedeflenmiştir. Çalışmanın temel amacı, halihazırda kullanılan nörobilim tekniklerini etik bakış açıs ile tartışmaktır. Konunun artan popularitesi, örgütsel nörobilim alanında düzenlenen konferans, kongre ve dergilerin bu konuya ayrılmış özel sayılarından ileri gelmektedir. Ancak sosyal davranışın bu iki displininin teorik kodları bir yandan sosyo biyolji ile evrimsel psikolojinin diğer yandan ise sosyal psikolojinin hiç de kolay olmayan kucaklaşmasından türetilmektedir.

Anahtar Kelimeler: Nörobilim, örgütsel nöro bilim teknikleri, sosyal bilişsel nöro bilim, örgütsel davranış, etik sikıntılar.

\footnotetext{
${ }^{1}$ Yrd. Doç.Dr., Toros Üniversitesi,İIBSSF İktisat Bölümü, yogune@yahoo.com
} 


\section{INTRODUCTION}

Developments and new findings on "brain" are reshaping traditional views of organizational structure and management. Thus growing body of researchers focused on same question "what benefit understanding of the human brain will provide for the science and practice of management". Advance findings in neuroscience are expanding our understanding of behavior at workplace (Boyatzis, Smith, \& Blaize, 2006 in the David, A. Waldman, P.A, Balthazard, \& Suzanne J. P. 2009). Ochsner and Lieberman (2001) defined social cognitive neuroscience as an emergent, interdisciplinary field that seeks to understand human interactions at the intersection of social, cognitive, and neural spheres of science. A number of techniques are now available to investigate brain that may be relevant to desired and effective work behavior. This paper aims to enlighten this new multidisciplinary field and to lead researcher's attention to this young issue.

Social science is highly younger than natural science, so interdisciplinary definition problem is inevitable for the field. It is crucial to discuss the differences and similarities in the different theoretical positions. However, it must be understood that a comparative discussion of Becker et al.'s (2011) organizational neuroscience (ON), social cognitive neuroscience (SCN e.g. Blakemore et. al, 2004), and organizational cognitive neuroscience (OCN e.g. Senior et al. 2011) should not be understood as merely semantic, nor as simply terminology trick. These discipliners should not be seen as mutually unique or competing concepts (cf. Kuhn, 1970). Becker et all (2011) indicated in their study that organizational cognitive neuroscience is symbiotic with organizational neuroscience same as social cognitive neuroscience, to form a detailed theoretical framework that helps scholars to understand the complexities of the social behavior that occurs within organizations. From an anatomical approach to a cognitive approach, social cognitive neuroscience focuses on mediating of social cognition and behavior by biologic approach, while organizational cognitive neuroscience questioning relation of cognition and behavior at workplace (see Butler et al, 2007; Decety \& Keenan, 2006, in the Senior \& Butler, n.d.)

\section{TECHNIQUES IN USE}

Technology of neurological assessment and studies has advanced greatly in recent years. A number of techniques are now available to investigate brain activity that may be relevant to effective work behavior. Two of the more popular ones are functional magnetic resonance imaging (fMRI) and quantitative electroencephalogram (qEEG) (Hines 1987).

Current brain imaging techniques can classify under three main classes; structural, functional and metabolic. Many publications considered functional and metabolic imaging methods in combination. However, rapid advances in the metabolic process and the importance of the results obtained by this method in psychiatry, shows that the proper classification of a metabolic process should be separate group (Ceylan,2012 in the Kele \& Kol, 2015).

Neuroscientists use many measurement methods to measure neural activity. Includes methods such PET (positron emission tomography), fMRI (functional magnetic resonance imaging), EEG (electro-Encephalography), ERP (event related potential), biological blood, urine, determination of spinal fluid, to assess patients with central nervous system lesions (Zak, 2004: 1739).

PET has been used on humans for the first time in the early 1970s. PET main principle is as follows: A liquid is injected into the patient intravenously which makes radioactive radiation. The patient is placed inside a device that detects the radioactive decay. When radioactive gamma rays emitted reaction occurs, glucose and oxygen is start to 
consumed, so these begin to blood flow in this cells. PET measures the accumulation of radioactive substances in the brain, how fast glucose metabolism exceeds, it becomes more blood flow in the area and emits more gamma rays. A computer algorithm also draws the measurement of regional cerebral blood flow in the brain by three dimensions (Zak, 2004: 1739).

fMRI between different regions of the brain such as PET neural activity associated with the blood circulation and a brain imaging technique that measures changes in oxygen use. Used in humans for the first time in 1992, this technique is the most widely used technique nowadays. It called as BOLD, imaging depends on the blood oxygen content (Zak, 2004: 1739).

EEG measures the electrical activity of large groups of neurons through electrodes placed on the skin head. EEG is the printing process of electrical activity of brain waves produced during both sleeping and vigilance time. EEG method is in use clinically in diagnosis of neurological disorder, especially epilepsy. Finally ERP, shows the activity arising during a cognitive process. ERP characteristics of regional wave define the neural stimulating or inhibiting activity (Zak, 2004: 1740).

Chronic mental disorder (e.g. schizophrenia), developmental disorders (e. g. Autism) and nervous system diseases serve to understanding how the brain works. Many diseases are associated with certain regions of the brain. Finally, it is quite a new method, transcranial magnetic stimulation (TMS) to be mentioned. In this method, by creating strong but short external magnetic field and thus brain activity changes, thus therapeutic effect occurs. (Camereret et all, 2005: 13)

\section{CURRENT POINT}

Almost 40 years ago, Mintzberg (1976) point out that left brain/right brain differences may be relevant to management and leadership studies. Specifically, he discussed that managers may differ in relative strength or dominance with regard to two hemispheres of the brain; (emotional response) may make good managers or leaders. While some researchers (e.g. Kaminski-da-Roza, 1984; Hines, 1987) were approach very critical to "left brain and right brain mythology," advancements in neuroscience theories, methodologies, and findings over the last decade have led to a renewed interest in and exploration of brain theories.

As summarized by Finkelstein and Hambrick (1996), dominant left hemispheres (i.e., in which the focus is largely logic and rational thinking) may convert the managers good planners. In contrast, they suggested that managers with dominant right hemispheres in which the focus is largely imagination, creativity, visual imagery. Before some impressive experimental research samples about context and preexisting schemas of organizational actors involved in neuroscience (Eisenhardt 1989); below Figure 1, shows the dimensions of behavior at workplace. 


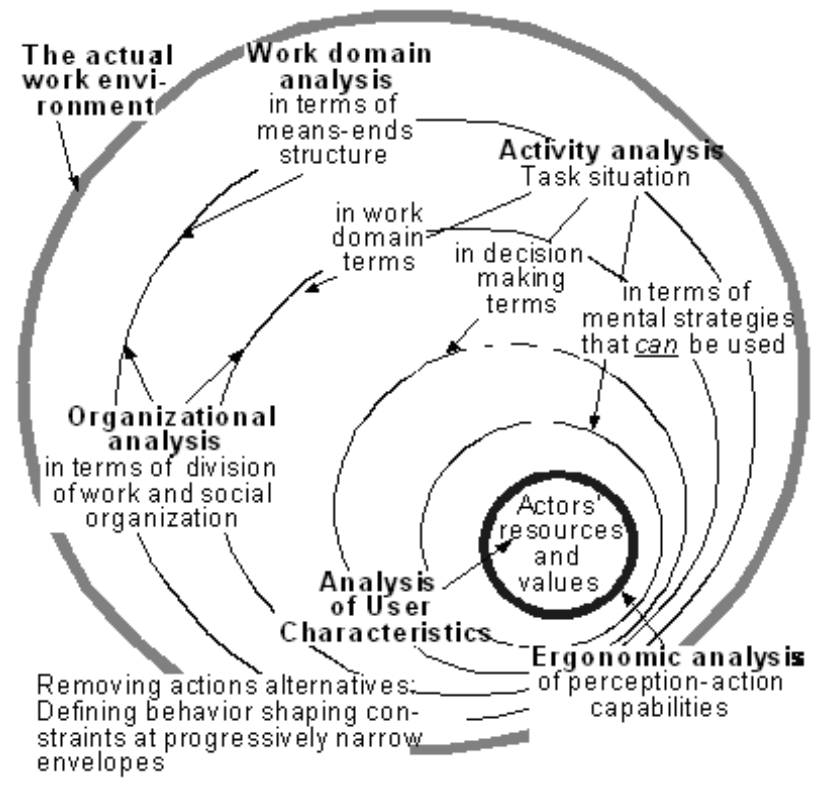

\section{Source: http://www.informationr.net/ir/10-1/paper210.html}

Figure 1: Dimensions of Cognitive Work Analysis

A key challenge for researchers is to attempt to make theoretical connections between brain activity and workplace behavior. For instance, researcher claims that the presence of high coherence in the right hemisphere could suggest greater emotional balance and understanding through integration in the processes that manage emotional thought, including an understanding of one's own emotions as well as the others emotions (Thatcher, Krause, \& Hrybyk, 1986; Thatcher, North, \& Biver, 2007).

Researchers have proposed a specific neurological basis for emotional intelligence or skills (Ashkanasy, 2003; Goleman, Boyatzis, \& McKee, 2001). Goleman et al. (2001) point out that emotional intelligence value has a basis in brain circuitry and further they suggested that it derives from how cortical regions of the brain interpret and manage neurotransmitter signals from the brain's limbic system. Morse (2006) shows that a leader's use of emotions and reasoning for the purpose of formulating and claims a vision has a basis in the limbic system. Further it is suggested that parts of the brain, such as the ventromedial prefrontal cortex, may help a person to balance emotions in decision making, especially in situations in ambiguous or uncertain (Naqvi, Shiv, and Bechara, 2006). There is also recent search showing that regions of the cortex may help to assess risk and guide behaviors in anticipation of emotive consequences, including such negative emotions; fear and despair (Paulus, Rogalsky, Simmons, Feinstein, \& Stein. 2003; Sanfey, et all \& 2003; Heisel and Beatty (2006). In those studies it is found that the right frontal part of the brain is essential for effective interpersonal communication and social relationships. Further, it has been shown that right frontal dysfunction gives rise to antisocial behavior and an inability to understand relationships with other people (i.e., social skills, emotion control, and self-awareness; (Salloway, Malloy and Duffy, 2001) and difficulties balancing emotions in decision making under conditions of uncertainty (Naqvi et al., 2006).

Recent advances in this field offer evidence of how the human brain might support leaders in many aspects of cognition and behavior. Neural basis for the construction of social knowledge, in particular the manner in which social inferences about the feelings, thoughts, and intentions of others are formed is proposed by Adolphs (2009). Tabibnia, Satpute, and 
Lieberman (2008) examined brain activities of managers in relation to perceptions of fairness versus unfairness. Below some common topics and related studies of the field, is listed:

Many researchers studied the importance of trust (e.g., Lewicki, McAllister, \& Bies, 1998; McAllister, 1995) also Zak and friends (2007) studied on how people make decisions around trust. Walsh et al. (1988) examined how political influences in group decision making affected how a collective decision schema was constructed (i.e., negotiated) and employed

Phelps (2006) shows the fear response linkages between the cortex or thalamus and the limbic areas, specifically the amygdala which can be considered under uncertainty responses at workplace studies.

Moral judgment is also relevant to decision making at workplace. Neuroimaging has established that locations in the frontal cortex are involved in moral judgment and evaluations of fairness, as well as morally based emotions such as compassion, indignation, and guilt (Knabb, Welsh, Zie- bell, \& Reimer, 2009).

Impact of genetic factors on behavior at workplace is studied by Arvey, Rotundo, Johnson, Zhang, McGue (2006) and Arvey, Zhang, Avolio,\& Kruger, (2007). Rafaeli et al. (1997) found that when female administrators were at work environment, their self-perception would interact with their observations of their own dress to make salient distinctive role perceptions (in the (Elsbach et al. 2005)

In a study of 62 software development teams, Levesque et al. (2001) found that many teams that had higher role definition among members at the beginning of a project reported less interaction among members a month later, and consequently after three months working together less shared mental models revealed.

Shared cognition which is very essential for team studies in organizational behavior is studied by Thompson et al. (1999). They studied the overlapping knowledge structures and content of individuals in groups, organizations, and industries. Furthermore there is evidence that the value of collective cognition for improving organizational performance may depend on individuals assuming a collectivist approach or mindset to problem solving. Interestingly, a few case studies suggest that such a collectivist mindset may arise when individual own schemas interact with the socio-dynamic contexts (e.g., Cohen and Bacdayan 1994, Sutton and Hargadon 1996, Okhuysen 2005). Cohen and Bacdayan's (1994) study of collective memory shows the importance of having a collectivist mindset to the emergence of situated cognition at the supra-individual level.

As a last, in their very impressive research Weick and Roberts (1993) examined the flight deck of an aircraft carrier about collective processes that enabled this organization to maintain high reliability in spite of the necessity of repetitive cycling through routines.

\section{ETHICAL CONSIDERATIONS Of THE NEURO TECHNIQUES}

Reviewing the studies in the literature, it is predictable that, in the future brain imaging techniques can provide a lot of data in many areas. But at this point it is necessary to note the presence of some ethical concerns. As we move forward, it is also important to recognize the moral and ethical implications of work directed toward linking neuroscience and organizational behavior. Free choice matter and self-determination rights of individuals should shape the potential future experimental studies. Furthermore, when assessing the scientific and ethical terms the human health and the interests of individuals must be at the forefront of society (Frost and Lumia, 2012). 
In studies conducted on brain imaging; ethical, social and legal issues are set to emerge and "neuro-ethics" concept addresses these issues (Senior \& Lee, 2013). Ethical considerations can classify under two topics; first to what extent gathered data could be useful at workplace secondly; is it possible to provide objectivity of researcher. As obviously seen there are a great number of questions waiting to be answer, in the field.

Despite of all good advantageous of neuro studies at workplace, there is a darker side exists with regard to behavior manipulation and employee rights (House \& Howell, 1992). Organizational development (satisfaction, commitment, motivation, leadership, effective decision making at workplace) is a multi-billion dollar industry, within house as well as external consulting groups offering employee development techniques and programs for their clients (David, A. Waldman, P.A, Balthazard, \& Suzanne J. P. 2009). It is imperative that future efforts to use neuro feedback for the purpose of organizational effectiveness development be cognizant of such distinctions, and that attempts be made to promote only positive uses of such technologies.

\section{DISCUSSION}

Lieberman (2007, p. 279), who suggested that social cognitive neuroscience "can contribute to the development of new theories and the enrichment of existing theories within the social sciences, demonstrating that social cognitive neuroscience can be both a science of new techniques and a science of new ideas." To map the brain as today the world's leading countries is carried out big-budget project scientific research because by using neuroscience at workplace, to increase effectiveness and efficiency is obviously possible. In this study, it is aimed to explain the point of neuroscience studies at workplace behavior with regard to organizational behavior field. Attempt to introduce some techniques and terminology of neuroscience by reviewing literature. The main aim of the paper is to understand the point of neuroscience studies at workplace so there are good samples of experimental research. Besides brain imaging techniques and data obtained as a result of these techniques it is noted that there are many ethical problems of interpretation of obtained data. We also consider ethical implications and applications to management-related areas beyond leadership. Despite growing number of studies, there is a problem of lack of inter-disciplinary research in the field, still. In Turkey there is some research on organizational neuroscience carried out by various universities. This knowledge could be useful to organizations that undertake extensive efforts to identify and improve behavior and skills. It is important to share gathered data with the managers and company owners to improve better results. But, it is important to recognize the potential contributions of additional synergistic research intersections to illuminate neuro behind behavior and organizational theory. May be future embracing of neuro-science, genetics, evolutionary psychology and organizational research will provide benefit more than current expectations. For instance, there is early evidence (Lee \& Chamberlain, 2007) that genetics may influence brain processes, such as the efficiency of the prefrontal cortex and sensitivity of the amygdala, which in turn may affect leadership behaviors. So considering potential improvements of this young field below list can be potential development directions for future research; (Meindl et al. 1994)

- $\quad$ In the future, the most important studies will clearly make closer net between cognition, behavior, and organizational outcomes.

- In the future, the field will remove wall down its conceptual arena to focus on the most promising concepts and methodologies.

- In the future, temporal concepts such as interpretive dominance may help us to escape from tired old problems related to level-of-analysis. 

content and process.

- In the future, the most interesting and productive studies will integrate

- In the future, we will see more attention given to the role of information systems in managerial cognition.

\section{REFERENCES}

Adolphs, R. (2003); Special issue on cognitive neuroscience of social behavior. Neuropsychologia 41, 117

Adolphs, R. (2009). The social brain: Neural basis of social knowledge. Annual Review of Psychology, 60, 693-716

Arvey, R. D., Rotundo, M., Johnson, W., Zhang, Z., \& McGue, M. (2006). The determinants of leadership role occupancy: Genetic and personality factors. The Leadership Quarterly, 17, 1-20.

Arvey, R. D., Zhang, Z., Avolio, B. J., \& Kruger, R. F. (2007). Developmental and genetic determinants of leadership role occupancy among women. Journal of Applied Psychology, 92, 693-706.

Ashkanasy, N. M. (2003). Emotions in organizations: A multi-level perspective. Research in Multi-Level Issues, 2, 9-54

Becker, W. J., \& Cropanzano, R. (2010). Organizational neuroscience: The promise and prospects of an emerging discipline. Journal of Organizational Behavior, 31, 10551059.

Bergué, C. D. (2010). Brain and human behavior in organizations: A field of neuroorganizational behavior. In A. A. Stanton, M. Day \& I. M. Welpe (Eds.), Neuroeconomics and the firm. Northampton, MA: Edward Elgar.

Boyatzis, R. E., Smith, M. L., \& Blaize, N. (2006). Developing sustainable leaders through coaching and compassion. Academy of Management Learning \& Education, 5, 8-24.

Cacioppo, J. T. (2001). et al. (eds) Foundations in Social Neuroscience (MIT Press, Cambridge, Massachusetts.

Camerer, C. F., Loewenstein, G. F. \& Prelec, D. (2005). Neuroeconomics: How Neuroscience Can Inform Economics. Journal of Economic Literature, 43(1), 9- 64.

Cohen, M. D.\& P. Bacdayan. (1994). Organizational routines are stored as procedural memory: Evidence from a laboratory study. Organ. Sci. 5 554-568.

David, A. Waldman, P.A, Balthazard, \& Suzanne J. P. (2009). Can We Revolutionize the Way That Inspirational Leaders Are Identified and Developed? Information Systems, $60-75$.

Eisenhardt, K. M. (1989). Building theories from case study research. Acad. Management Rev. 14 532-550. In Elsbach et al., 2005

Elsbach, Barr, \& Hargadon. S. (2005). Identifying Situated Cognition in Organizations Organization Science 16(4), pp. 422-433.

Finkelstein, S., \& Hambrick, D. (1996). Strategic leadership: Top executives and their effects on organizations. St. Paul, MN: West Publishing 
Frost , C. J., \& Lumia, A. R. (2012). The Ethics of Neuroscience and the Neuroscience of Ethics: A Phenomenological-Existential Approach. Sci Eng Ethics 18:457-474, DOI 10.1007/s11948-012-9388-1.

Goleman, D., Boyatzis, R., \& McKee, A. (2001). Primal leadership. Boston, MA: Harvard Business School Press.

Heatherton, T. F. \& Macrae, C. N. (2003). Social Cognitive Neuroscience: A Reader Blackwell, Cambridge, Massachusetts

Heisel, A. D., \& Beatty, M. J. (2006). Are cognitive repre- sentations of friends' request refusals implemented in the orbitofrontal and dorsolateral prefrontal cortices? A cognitive neuroscience approach to 'theory of mind' in relationships. Journal of Social and Personal Relationships, 23, 249-265.

Hines, T. (1987). Left brain/right brain mythology and implications for management and training. Academy of Management Review, 12, 600-606.

Kaminski-da-Roza, V, (1984) Managing the "right-brain" half of salary review. Supervisory Management, 29(2), 8-11.

Kent, O. (2011). Ana Akıma Bir Alternatif : Nöroiktisat Alternatıve To The Maınstream :, Istanbul Ticaret Üniversitesi Sosyal Bilimler Dergisi, pp.157-176

Knabb, J. J., Welsh, R. K., Ziebell, J. G., \& Reimer, K. S. (2009). Neuroscience, moral reasoning, and the law. Behavioral Sciences \& the Law, 27, 219-236.

Kuhn, T. S. (1970). The Structure of Scientific Revolutions, 2 ed. University of Chicago Press, Chicago: IL.

Lee N \& Chamberlain L. (2007). Neuroimaging and psychophysiological measurement in organizational research: an agenda for research in organizational cognitive neuroscience. Annals of the New York Academy of Sciences. 1118.18-42.

Levesque, L. Wilson, L., J. M. \& Wholey, D.R. (2001). Cognitive divergence and shared mental models in software development project teams. J. Organ. Behavior 22 135144.

Lewicki, R. J., McAllister, D. J., \& Bies, R. J. (1998). Trust and distrust: New relationships and realities. Academy of Management Review, 23, 438-458.

McAllister, D. J. (1995). Affect- and cognitionbased trust as foundations for interpersonal cooperation in organizations. Academy of Management Journal, 38, 24-59.

Meindl, J. R., Stubbart, C., \& Porac, J. F. (1994). Cognition Within and Between Organizations: Five Key Questions. Organization Science, 5(3), 289-293. http://doi.org/10.1287/orsc.5.3.289.

Mintzberg H. (1976). Planning on the left side and manag- ing on the right side. Harvard Business Review, 54, 49- 58.

Naqvi, N., Shiv, B., \& Bechara, A. (2006). The role of emotion in decision making: A cognitive neuroscience perspective. Current Directions in Psychological Science, 15, 260-264.

Ochsner, K. N., \& Lieberman, M. D. (2001). The emer-gence of social cognitive neuroscience. American Psychologist, 56, 717-734 In ( David, A. Waldman, P.A, Balthazard, \& Suzanne J. P. 2009) 
Okhuysen, G. A. (2005). The creation and change of group rou- tines: Learning in a SWAT team. K. Elsbach, ed. Qualitative Organizational Research, Best Papers from the Davis Conference on Qualitative Organizational Research. Information Age Publishing, Greenwich, CT, 139-168.

Paulus, M. P., Rogalsky, C., Simmons, A., Feinstein, J. S.,\& Stein, M. B. (2003). Increased activation in the right insula during risk-taking decision making is related to harm avoidance and neuroticism. NeuroImage, 19, 1439-1448.

Phelps, E. A. (2006). Emotion and cognition: Insights from studies of the human amygdala. Annual Review of Psychology 57, 27-53.

Rafaeli, A., J, Dutton, C. V, Harquail, S. \& Mackie-Lewis. (1997). Nav igating by attire: The use of dress by female administrative employees. Acad. Management J. 40 9-45.

Salloway, S. P., Malloy, P. F., \& Duffy, J. D. (2001). The frontal lobes and neuropsychiatric illnesses. Washington, DC: American Psychiatric Publishing.

Sanfey, A. G., Rilling, J. K., Aronson, J. A., Nystrom, L. E., \& Cohen, J. D. (2003). The neural basis of economic decision-making in the ultimatum game. Science, 300, $1755-1758$.

Senior, C., Lee, N., \& Butler, M. (2011). Organizational cognitive neuroscience. Organ. Sci 22, 804-815. doi: 10.1287/orsc.1100.0532.

Senior, C., \& Lee, N. (2013). The state of the art in organizational cognitive neuroscience: the therapeutic gap and possible implications for clinical practice. Frontiers in Human Neuroscience, http://doi.org/10.3389/fnhum.2013.00808.

Sutton, R. I.\& A. B. Hargadon. (1996). Brainstorming groups in context: Effectiveness in a product design firm. Admin. Sci. Quart. 41 685-718.

Tabibnia, G., Satpute, A. B., \& Lieberman, M. D. (2008). The sunny side of fairness: Preference for fairness activates reward circuitry (and disregarding unfairness activates self-control circuitry). Psychological Science, 19, 339-347.

Thatcher, R. W., Krause, P., \& Hrybyk, M. (1986). Corti- cocortical association fibers and EEG coherence: A two compartmental model. Electroencephalography and Clinical Neurophysiology, 64, 123-143.

Thatcher, R. W., North, D., \& Biver, C. (2007). Develop- ment of cortical connections as measured by EEG coher- ence and phase delays. Human Brain Mapping, 29, 1400 1415.

Walsh, J. P., C. M. Henderson, J\& Deighton. (1988). Negotiated belief structures and decision performance: An empirical investigation. Organ. Behavior Human Decision Processes 42 194-216.

Zak, Paul J. (2004). Neuroeconomics. Philosophical Transactions of the Royal Society of London Series: B, 359(1451) 1737-1748. In the (Kent 2011)

\section{Web sources:}

http://www.informationr.net/ir/10-1/paper210.html Access Date: 21.07.2015

http://eminceylan.com/pro1.asp?CatID=128 Ceylan, M. E. (2012, 12 23). ProfesyonellerBeyin Görüntüleme. Prof.Dr.Mehmet Emin Ceylan Psikiyatrist, Farmakolag: Access Date: 22.07.2015 